\title{
Diagnostic Power and Pitfalls of Intraoperative Consultation (Frozen Section) in Rhabdomyosarcoma
}

\author{
Rabdomyosarkomda İntraoperatif Konsültasyonun (Frozen İnceleme) \\ Tanısal Gücü ve Tuzakları
}

\author{
Olcay KURTULAN, Kemal KÖSEMEHMETOĞLU
}

Department of Pathology, Hacettepe University, Faculty of Medicine, ANKARA, TURKEY

\begin{abstract}
Objective: Intraoperative consultation plays an important role in the management of soft tissue sarcomas, such as rhabdomyosarcoma. In this study, we aimed to draw attention to the important points during frozen section interpretation, and analyse the accuracy of frozen diagnosis in rhabdomyosarcoma patients.
\end{abstract}

Material and Method: The cases, both diagnosed as rhabdomyosarcoma or followed with a history of rhabdomyosarcoma, and interpreted with intraoperative consultation (frozen section) between 2000 and 2013 were culled from pathology archives. The diagnoses were confirmed by desmin and myogenin, immunohistochemically. The frozen and final diagnoses were noted of 21 biopsy specimens of 19 patients. Sensitivity and specificity of intraoperative consultation were calculated regarding to the major diagnostic discrepancies leading to a change in surgical management of the patient, after exclusion of the cases deferred to paraffin section.

Results: Of the evaluated 21 biopsy material, 3 (14\%) were misdiagnosed: Of the 2 false negative embryonal rhabdomyosarcoma cases, sample was not representative of the tumor, and there was chemo/radiotherapy induced changes in the other case. In the only false positively diagnosed case with a known history of rhabdomyosarcoma, inflammatory cells were misinterpreted as small round cell neoplasm. In 5 (29\%) of 21 biopsies, a frozen diagnosis could not be given, and the diagnosis was deferred. Six cases (29\%) were evaluated with cytological squash or imprint preparation; none of the misdiagnosed cases was evaluated with adjunct cytological preparation. Six of 8 misdiagnosed or deferred biopsies showed morphological changes secondary to radiotherapy and/or chemotherapy. Sensitivity, specificity, positive predictive value, and negative predictive value were calculated as $85 \%, 67 \%, 92 \%$ and $50 \%$, respectively.

Conclusion: Intraoperative consultation for rhabdomyosarcoma is a reliable tool with high sensitivity and fair specificity. Cases with treatment effect may lead to diagnostic difficulties, especially false negative results. Understanding the diagnostic algorithm of surgeon may prevent misdiagnosis of frozen specimen. Our results also emphasize the diagnostic role of intraoperative cytology as an adjunct to frozen section.

Key Words: Rhabdomyosarcoma, Sarcoma, Cytology, Diagnostic errors

(Turk Patoloji Derg 2015, 31:16-23)

Received : 26.08.2014 Accepted : 18.09.2014
ÖZ

Amaç: Rabdomyosarkom gibi bazı yumuşak doku tümörlerinde intraoperatif konsültasyon olgunun yönetiminde önemli rol oynamaktadır. $\mathrm{Bu}$ araştırmada, rabdomyosarkom tanısı alan olgularda frozen tanı doğruluğu analiz edildi ve frozenda dikkat edilmesi gereken noktaların belirlenmesi amaçlandı.

Gereç ve Yöntem: Patoloji arșivinden 2000-2013 yılları arasında intraoperatif konsültasyon (frozen) yapılmış ve rabdomyosarkom tanısı almış veya rabdomyosarkom hikayesi olan olgular tarandı; immünohistokimyasal olarak myogenin ve desmin ile tanıları teyid edildi. Ondokuz hastanın 21 biyopsisine ait frozen ve nihai tanıları kaydedildi. İntraoperatif konsültasyonun sensitivite ve spesifisitesi hesapland1; bu hesaplarda cerrahiyi değiştirecek majör uyumsuzluklar göz önünde bulunduruldu ve parafine birakılan olgular dışlandı.

Bulgular: Değerlendirmeye alınan 21 biyopsi örneğinin 3’ü (\%14) yanlış tanı almıştır: 2 yanlış negatif embryonel tip rabdomyosarkom olgusunun birinde frozena gönderilen örnekte tümör temsil edilmemektedir. Diğer olguda ise kemo/radyoterapiye ikincil değişiklikler mevcuttur. Yanlış pozitif tanı verilen rabdomyosarkom öyküsü bilinen olguda inflamatuvar hücreler küçük yuvarlak hücreli neoplazi olarak değerlendirilmiștir. 21 biyopsinin 5'inde (\%24) intraoperatif konsültasyon tanısı verilememiș ve kesin tanı parafine bırakılmıştır. Olguların 6’sı (\%29) imprint veya kazıma şeklinde sitolojik preparasyon eşliğinde değerlendirilmiştir; yanlış tanı almış olguların hiç birinde sitolojik preparasyon yapılmamıștır. Parafine bırakılan veya yanlış tanı alan 8 biyopsiden 6'sında morfolojik olarak kemoterapi ve/veya radyoterapiye ikincil değişiklikler olduğu görülmüştür. Frozen tanı sensitivitesi $\% 85$, spesifitesi $\% 67$, pozitif prediktif değeri $\% 92$, negatif prediktif değeri $\% 50$ olarak hesaplanmıştır.

Sonuç: Rabdomyosarkom için intraoperatif konsültasyon yüksek sensitivite ve ortalama spesifisite ile oldukça güvenilir bir araçtır. Tedavi etkisi gösteren olgular tanısal zorluklara özellikle de yanlış negatif sonuçlara yol açabilir. Cerrahın tedavi algoritmasını tam olarak anlamak yanlıș tanıyı engelleyebilir. Ayrıca sonuçlarımız frozen kesite ek olarak yapılan intraoperatif sitolojinin tanısal rolünü vurgulamaktadir.

Anahtar Sözcükler: Rabdomyosarkom, Sarkom, Sitoloji, Tanısal hatalar

Correspondence: Kemal KÖSEMEHMETOĞLU

Hacettepe Üniversitesi, Tip Fakültesi, Patoloji Anabilim Dalı, 06100, Sthhiye, Ankara, TURKEY

E-mail: dokemal@hotmail.com Phone: +90 5442147073 


\section{INTRODUCTION}

Surgical pathologists inevitably have to deal with soft tissue tumours not only on routine pathology workup, but also at frozen section. Nevertheless, there are encouraging results in the literature designating the reliability of frozen section in soft tissue tumors for general rather than exact diagnosis in defining the previously unknown pathologic process (1). Intraoperative consultation may have some important role, especially for determination of surgical margins, presence of diagnostic material, and separation of fresh material for molecular studies in the management of rhabdomyosarcoma (RMS), the most common sarcoma of children and adolescents $(2,3)$.

In this study, we assessed the diagnostic accuracy of intraoperative consultation in RMS in our department. We aimed to emphasize the reasons leading to misdiagnosis, and to define the specific morphologic findings to reach the correct diagnosis.

\section{MATERIAL and METHODS}

We re-examined the slides of 25 biopsies from 23 patients that underwent frozen-section evaluation for RMS between the years 2000 and 2013. Immunohistochemical studies for desmin (Biocare, Concord/CA, 1/50) and myogenin (DBS, Pleasenton/CA, 1/50) were performed using Leica Bond Polymer Refine Detection Kit (Leica, DS9800) and Leica Bond Max Autostainer Machine to confirm the diagnoses, and the presence of "PAX3-FOXO1A" fusion was shown in 3 cases of alveolar RMS. After review, 4 cases whose diagnoses could not be confirmed were excluded from the study. Remaining 21 biopsies from 19 patients were included in the study, and morphological features were noted.
Only the major differences that change the surgical management were considered for the assessment of diagnostic power (sensitivity, specificity, and predictive values) of frozen-section diagnoses.

\section{RESULTS}

Eight cases were male and 11 were female. The mean age was 16.5 (ranged between 1 and 68), and 12 (63\%) were under the age of 15 . After the re-examination of the slides, 11 cases (52\%) were diagnosed as embryonal RMS, 5 cases (24\%) as alveolar RMS, and 1 case (5\%) as pleomorphic RMS. Remaining 4 (19\%) cases were negative for tumour; 3 were followed-up with the previous diagnosis of embryonal RMS and 1 patient was only suspected for RMS. The tumour was localized to the head and neck in 15 patients (79\%), and the uterus, paravertebral region and prostate in 1 for each (5\%). Localization of tumour in 1 case was not available.

Three of the 21 biopsies (14\%) were misdiagnosed in intraoperative consultation; 2 had false negative, and 1 had false positive diagnoses (Table I). In one of the false negative cases, tumour was not represented in the small frozen biopsy material sent by surgeon (Figure 1A). Complete examination of the biopsy material sent to pathology department revealed hypercellular areas composed of neoplastic cells having round, monomorphic, hyperchromatic nuclei, and scanty cytoplasm (Figure 1B) besides the hypocellular and hyalinized zones which were seen in frozen section. Immunohistochemically, desmin and myogenin were positive in the neoplastic cells (Figure 1C,D).

In the other false negative case, the biopsy showed prominent chemo/radiotherapy related changes (Figure 2A-D), characterized by oedema and fibrosis with inflammatory background, and only a few atypical cells

Table I: List of deferred and misdiagnosed cases

\begin{tabular}{|l|c|c|}
\hline & $\begin{array}{c}\text { Intraoperative consultation diagnosis } \\
\text { (Frozen-section) }\end{array}$ & $\begin{array}{c}\text { The final diagnosis } \\
\text { (Paraffin-embedded section) }\end{array}$ \\
\hline False “+" Diagnosis & Small blue round cell tumour & Inflammation \\
\hline False “-" Diagnosis & Fibrosis and hyalinization & ERMS \\
\hline & No neoplasm & ERMS, prominent therapy related changes \\
\hline \multirow{4}{*}{$\begin{array}{l}\text { Indeterminate Frozen } \\
\text { diagnosis }\end{array}$} & Suspicious for malignancy & ERMS \\
\cline { 2 - 3 } & Suspicious for malignancy & Inflammation \\
\cline { 2 - 3 } & Possibly reactive changes & No neoplasm \\
\cline { 2 - 3 } & $\begin{array}{c}\text { Suspicious for malignancy } \\
\text { (Rhabdomyoblast/lymphocyte?) }\end{array}$ \\
\hline
\end{tabular}

ERMS: Embryonal rhabdomyosarcoma 


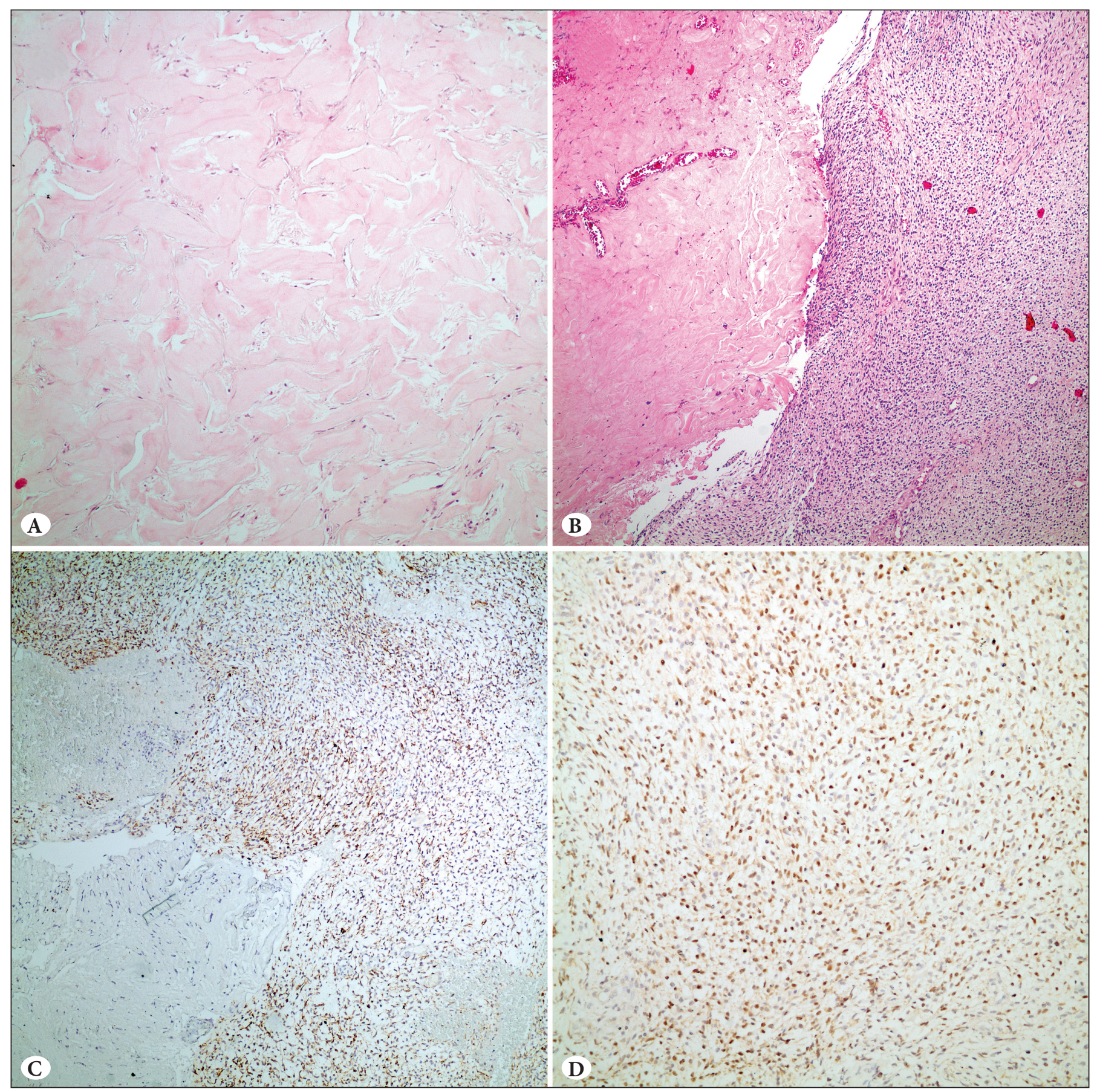

Figure 1: A) Hyalinized, hypocellular areas devoid of tumour on frozen section (H\&E; x200). B) Presence of hypercellular neoplasia on the right side and hyalinized areas on the left representing the areas seen in frozen section on paraffin section (H\&E; $\mathrm{x} 100)$. C) Cytoplasmic expression of desmin in the neoplastic cells (Desmin; x100). D) Nuclear myogenin expression (Myogenin; x200).

were present (Figure 2A). In the permanent section, atypical cells were present in the background of fibrosis and inflammation (Figure 2B). Atypical cells were in the form of strap cells with unipolar or bipolar eosinophilic cytoplasmic extensions, and hyperchromatic, irregular nuclei. Histological hallmarks, such as broken arrow sign
(Figure 2C), and immunohistochemical demonstration of myoid markers desmin and myogenin were diagnostic for RMS (Figure 2C,D).

Only one false positive case, previously diagnosed as RMS, and re-excised because of surgical margin positivity, was evaluated as having small blue round cell tumour in 


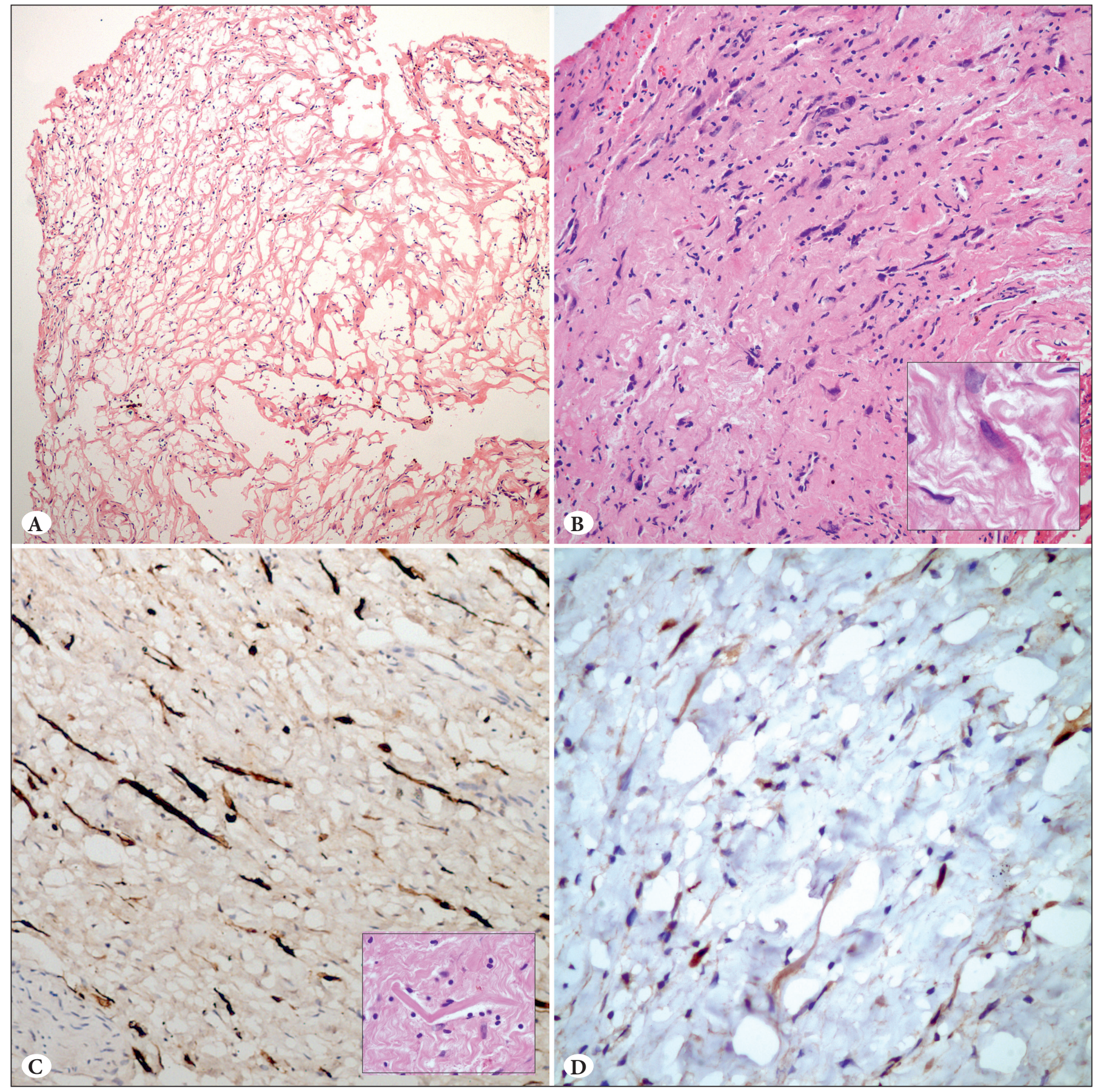

Figure 2: A) Oedematous and fibrotic changes on frozen section (H\&E; x100). B) Paraffin section of frozen material; atypical cells are seen in the background of fibrosis and inflammation (H\&E; x200). Some cells also show diagnostic striations (inset; $\mathrm{x} 400)$ C) Elongated cytoplasmic expression of desmin in the neoplastic cells corresponding to the broken arrow sign in H\&E (inset) (H\&E; $\mathrm{x} 400$ ). D) Nuclear expression of myogenin (Myogenin; x400).

frozen section (Figure 3A,B); however, it turned out to be an intensive inflammatory infiltrate and fibrosis in the permanent section (Figure 3C), and immunohistochemical analysis for myogenin was negative (Figure 3D).
Five biopsies (24\%) were reported as indeterminate during intraoperative consultation, and definitive diagnosis was left to permanent paraffin sections (Table I). Six out of 8 patients (75\%) who were misdiagnosed or had inconclusive result 


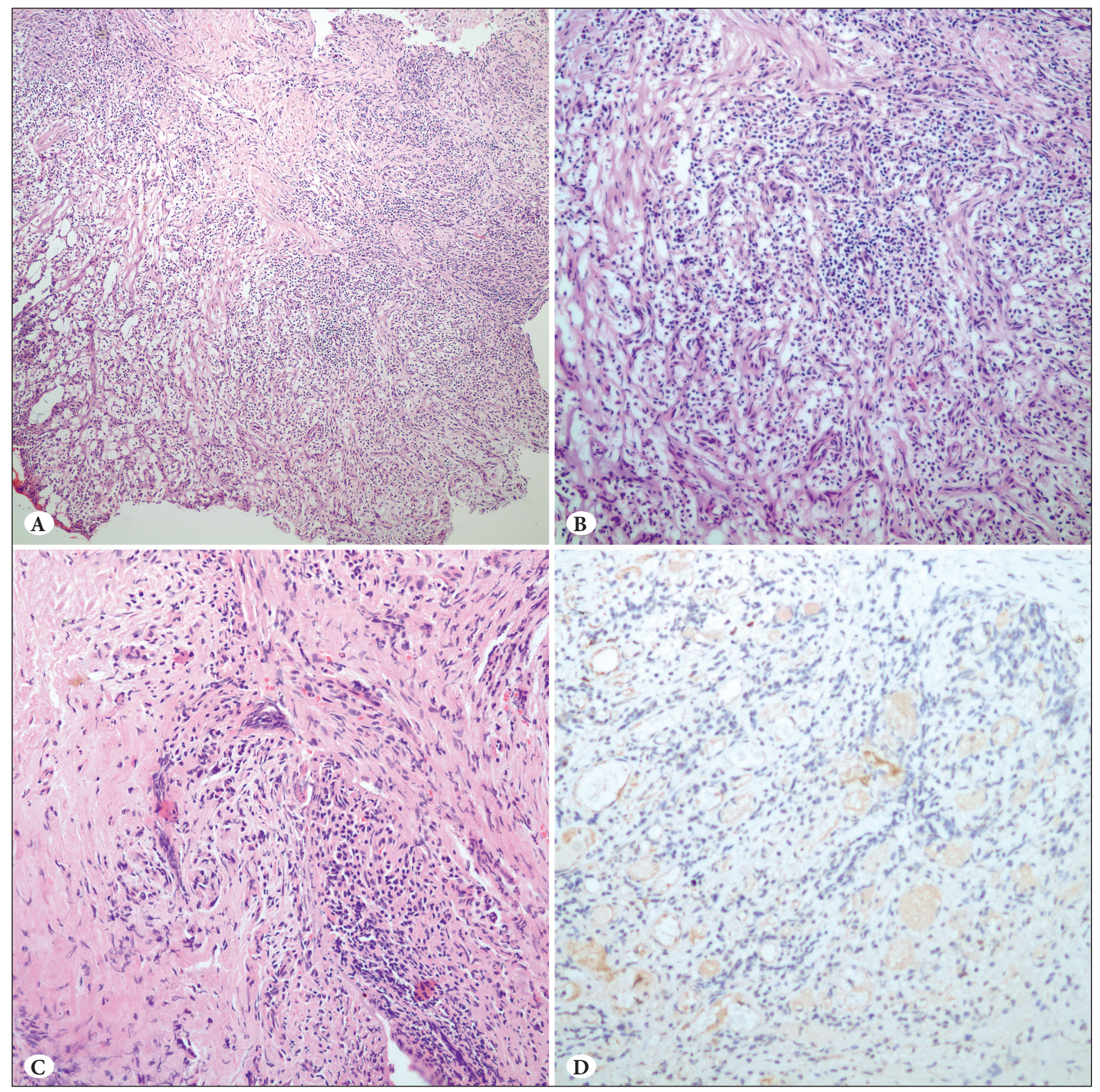

Figure 3: A,B) Frozen section: Intensive infiltrate of lymphocytes on vessel-rich background misinterpreted as small blue round cell tumour. C) Paraffin embedded section; Presence of chronic inflammation, granulation tissue and fibrosis was easier to recognize (H\&E; x200) D) Myogenin was also negative (Myogenin; x200).

during frozen section previously received chemotherapy or radiotherapy, and biopsies of these patients showed significant treatment related morphological changes, such as fibrosis, hyalinization, and inflammatory reaction (Figure 4A-D).
Sensitivity, specificity, positive and negative predictive values of intraoperative consultation diagnosis for RMS were calculated as $85 \%, 67 \%, 92 \%$, and $50 \%$, respectively. 


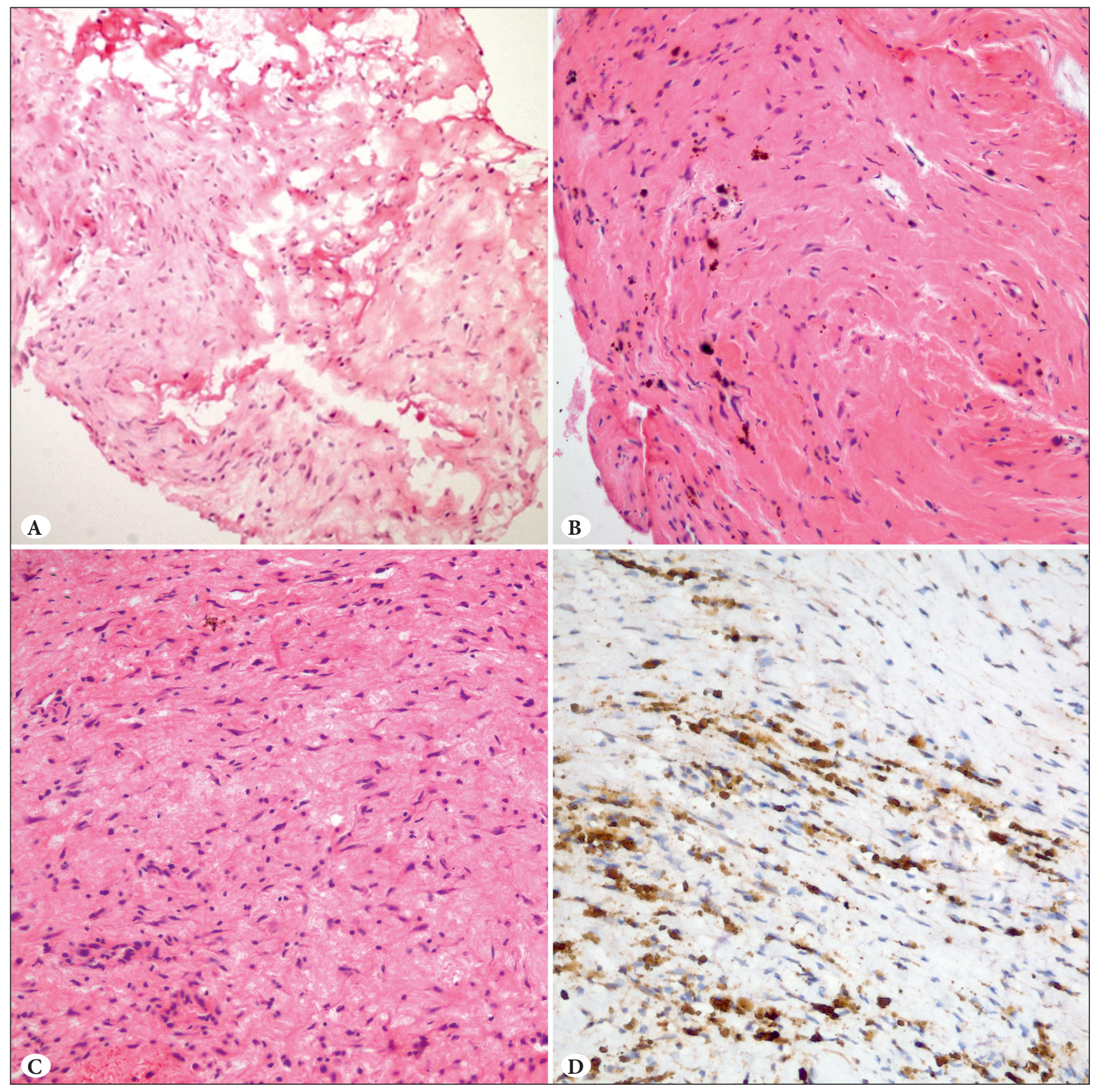

Figure 4: A,B) Fibroblast-like cells within collagenous background and hemosiderin pigment in both frozen and permanent sections. Due to the presence of scattered hyperchromatic cells, frozen diagnosis was "suspicious for malignancy, definitive diagnosis should be given in permanent sections" (H\&E; x100 and x200). C) Examination of remaining surgical material in paraffin sections revealed rhabdomyoblastic strap cells with unipolar or bipolar eosinophilic cytoplasmic extensions and hyperchromatic nuclei (H\&E; x200). D) Positive myogenin staining (circles) supported the diagnosis of RMS (Myogenin; x200).

Six of 21 cases (29\%) were evaluated with cytological preparations, and none of them was misdiagnosed in the intraoperative consultation. Also, squash smear examination was not performed in none of the cases with false frozen diagnoses. Microscopically cytological preparations were hypercellular, and had neoplastic cells with small, round, hyperchromatic nuclei, and scanty cytoplasm (Figure 5A,B). 


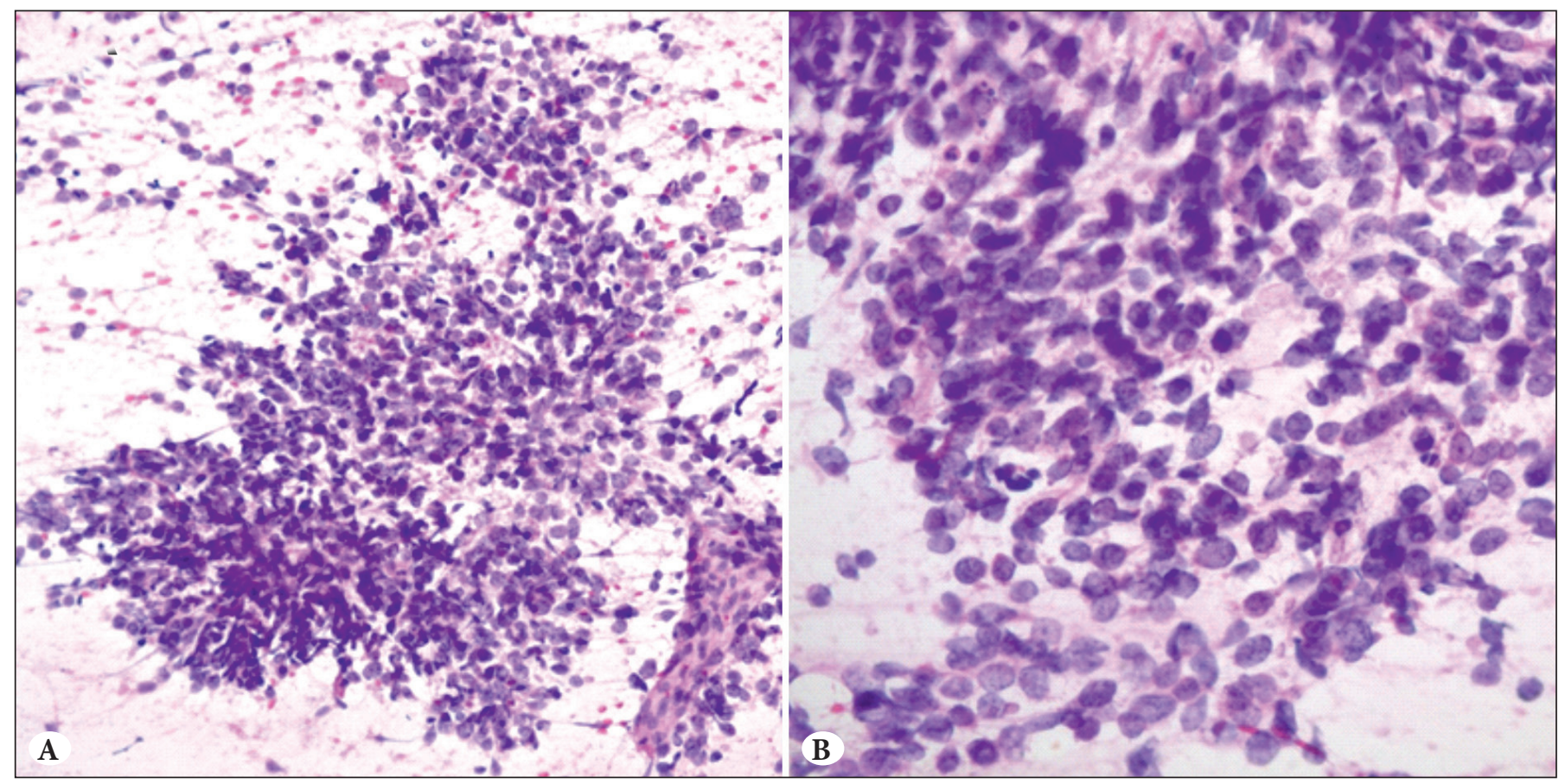

Figure 5: Cytological features of RMS in squash smears during intraoperative consultation (H\&E; x200 and x400).

\section{DISCUSSION}

Rhabdomyosarcoma (RMS) is a primitive, malignant softtissue tumour with phenotypical and biological features of embryonic skeletal-muscle cells. RMS has 4 distinct subtypes: embryonal, alveolar, pleomorphic, and spindle cell/sclerosing RMS, each having diverse morphology and differential diagnosis (4). What makes RMS the subject of the current study is that RMS is the most common softtissue sarcoma in children and adolescents, thus more frequently encountered in frozen section than any other rarer sarcomas. Moreover, in the USA, frozen triage of childhood RMS is highly recommended for national protocol studies (2), which is also expected to be valid for Turkey in the near future.

In soft tissue tumours, intraoperative consultation is useful in determining the surgical procedure, in assessing if the tumour is present and in constructing a differential diagnosis that can direct the proper triage of tissue for flow cytometry, electron microscopy, and molecular studies/ cytogenetics, particularly for neuroblastoma and RMS (2). Tissue triage is optimally performed at the time of frozen section. In many cases, it is important that a portion of tissue be submitted for ancillary studies, even from fineneedle aspiration (FNA) and core needle biopsy specimens, after sufficient tissue has been submitted for histological evaluation (5).
Frozen diagnosis for RMS is found to be highly sensitive, reaching $85 \%$; however, specificity is lacking, slightly better than flipping a coin. Therefore, it's recommended to be more careful while one decides to give "negative" result in frozen sections because of low specificity and negative predictive value. One should be especially careful about morphological pathognomonic clues, such as broken arrow sign and cross-striations, and a cytological squash preparation should be used as an auxiliary technique in order to prevent false negative results. Also, a complete understanding of the surgeon's treatment algorithm is recommended before rendering a frozen section diagnosis (6). According to the algorithm determination, the case could be released to paraffin embedded sections.

In our series, treatment-related morphological changes seem to have an important role leading to a false frozen section diagnosis. It is important to get the clinical history of patient if he/she had a working diagnosis of RMS previously or had received treatment. A variety of therapy-related histological changes ranging from necrosis, chronic inflammation, fibrosis to atrophic or regenerating nonneoplastic skeletal muscle have been reported in most RMSs, especially the embryonal subtype (7). Posttreatment specimens can show fibrosis, inflammation with macrophages and lymphocytes, and scattered neoplastic cells simulating reactive fibroblasts. Interpretation of therapy-induced differentiations is a great challenge for 
the pathologists and it is quite difficult to evaluate them in the frozen sections. The use of cytological preparations as an adjunct to frozen section is highly reliable tool (8), and may be quite useful for the differentiation of chronic inflammatory cells from small round rhabdomyoblasts and for the straightaway appreciation of the morphological details of the neoplastic cells.

Finally, we conclude that intraoperative consultation for RMS is a quite reliable tool with high sensitivity and fair specificity. Pathologists dealing with frozen section should be aware of treatment effect that may lead to diagnostic difficulties, especially false negative results. Understanding the diagnostic algorithm of the surgeon is highly recommended to prevent misdiagnosis. Our findings also encourage the use of intraoperative cytology as an adjunct to frozen section.

\section{REFERENCES}

1. Golouh R, Bracko M. Accuracy of frozen section diagnosis in soft tissue tumors. Mod Pathol. 1990;3:729-33.

2. Goldblum JR, Folpe AL, Weiss SW, Enzinger FM, Weiss SW. Enzinger and Weiss's soft tissue tumors. 6th ed. Philadelphia, PA: Saunders/Elsevier; 2014.

3. Qualman SJ, Bowen J, Parham DM, Branton PA, Meyer WH; Members of the Cancer Committee, College of American Pathologists. Protocol for the examination of specimens from patients (children and young adults) with rhabdomyosarcoma. Arch Pathol Lab Med. 2003;127:1290-97.
4. Fletcher CDM; World Health Organization, International Agency for Research on Cancer. WHO classification of tumours of soft tissue and bone. 4th ed. Lyon: IARC Press; 2013.

5. Hill DA, Bowen J, Coffin CM, Qualman SJ, Parham DM. Protocol for the examination of specimens from patients with rhabdomyosarcoma. http://wwwcaporg/ apps/docs/committees/cancer/cancer_protocols/2011/ Rhabdomyosarcoma_11protocolpdf Access date 8/20/2014 2011.

6. Rubin BP, Cooper K, Fletcher CDM, Folpe AL, Gannon FH, Hunt JL, Lazar AJ, Montag AG, Peabody TD, Pollock RE, Reith JD, Qualman SJ, Rosenberg AE, Weiss SW, Krausz T. Protocol for the examination of specimens from patients with tumors of soft tissue. http://wwwcaporg/apps/docs/committees/cancer/ cancer_protocols/2013/SoftTissue_13protocol_3120pdf Access date 8/20/2014 2013.

7. Coffin CM, Lowichik A, Zhou H. Treatment effects in pediatric soft tissue and bone tumors: Practical considerations for the pathologist. Am J Clin Pathol. 2005;123:75-90.

8. Scucchi LF, Di Stefano D, Cosentino L, Vecchione A. Value of cytology as an adjunctive intraoperative diagnostic method. An audit of 2, 250 consecutive cases. Acta Cytol. 1997;41:1489-96. 